\title{
HUBUNGAN PENGETAHUAN TERHADAP MOTIVASI DALAM MENCUCI TANGAN DALAM PENANGGULANGAN COVID-19 DI ERA PANDEMI
}

\author{
Fransiska Keron Ola \\ Sekolah Tinggi Ilmu Kesehatan Dirgahayu Samarinda \\ e-mail: cerollao@gmail.com
}

\begin{abstract}
ABSTRAK
Latar Belakang: Pandemi Covid-19 melanda Indonesia sejak bulan Maret 2020 dan di seluruh dunia. Dampak Pandemik Covid-19 sudah di lakukan pemerintah dan seluruh elemen masyarakat. Sangat di harapkan masyarakat berperan aktif dalam penanggulangan pencegahan covid-19 dengan cara menggunakan masker, menjaga jarak, mencuci tangan dengan baik dan benar di bawah air mengair serta melakukan social dictancing dengan cara menjauhi kerumunan dan menjaga jarak. Tujuan : Membahas pengetahuan terhadap motifasi mencuci tangan di dalam kehidupan seharihari. Metode:Penelitian kuantitatif dengan pendekatan cross sectional. Rancangan penelitian adalah survey analitik dengan cara penyebaran kuisioner melalui online dengan media Whatshap grup. Pengambilan sampel penelitian dengan cara total sampling. Pengolahan data menggunakan analisis korelasi spearman rank. Hasil : Hasil perhitungan distribusi pengetahuan mencuci tanngan $100 \%$ tidak baik, motifasi mencuci tangan $100 \%$ tidak pernah di lakukan. Hasil pengujian koefisien korelasi spearman rank 0,00 dengan kooefisien tingkat hubungan sangat rendah Kesimpulan: Kesimpulan dari penelitian adalah tidak ada hubungan antara pengetahuan terhadap motivasi mencuci tangan di dalam di kampus X Kota Samarinda dalam penanggulan Covid-19 di Era Pandemic.
\end{abstract}

Key Words: Pengetahuan, Motivasi, Mencuci Tangan, Covid-19, Era Pandemi

\section{PENDAHULUAN}

Pandemi penyakit virus korona 2019 (COVID-19) menimbulkan dampak yang sangat besar pada individu, keluarga, komunitas, dan masyarakat di seluruh dunia. Pada 13 April, lebih dari 1,7 juta orang telah terinfeksi, dan hampir 85.000 orang kehilangan nyawa. WHO berduka dengan semua keluarga yang kehilangan orang yang dicintai, dan memberi hormat kepada petugas kesehatan di seluruh dunia yang setiap hari membahayakan diri mereka sendiri untuk menyelamatkan nyawa.

Penyakit corona virus 2019 (COVID-19). Pada 30 Januari 2020, Komite Darurat Organisasi Kesehatan Dunia (WHO) menyatakan penyakit yang dikenal sebagai Penyakit Coronavirus 2019 (COVID-19) sebagai
Darurat Kesehatan Masyarakat Internasional (PHEIC), dan pada 11 Maret menyatakannya sebagai pandemi ("WASH Sector response to COVID19," 2020).

Salah satu masalah kesehatan utama adalah mencegah penyebaran COVID19. Jika anggota keluarga dinyatakan positif COVID-19 tanpa menunjukkan gejala apa pun, atau menunjukkan gejala yang terkait dengan COVID-19, menerapkan langkah-langkah untuk mencegah penyebaran infeksi lebih lanjut mungkin juga menantang. Tantangan ini menghambat upaya untuk menciptakan lingkungan yang kondusif untuk pembelajaran di rumah.(Note, Section, \& Technologies, n.d.). 
Epidemi saat ini ditandai dengan informasi dan nasihat kesehatan yang berlebihan (terkadang bertentangan atau menyesatkan) yang dapat menyebabkan keluarga mengambil tindakan yang salah informasi atau merasa kewalahan dan bingung.

Cuci tangan adalah cara yang mudah, murah, dan efektif untuk mencegah penyebaran kuman dan menjaga kesehatan anak-anak dan orang dewasa. Jika keluarga Anda sehat, Anda tidak perlu khawatir ketinggalan sekolah, pekerjaan, atau aktivitas lainnya.

COVID-19 mengancam semua negara di dunia, meskipun pada tingkat yang berbeda dan dengan cara yang berbeda. Epidemi sekarang telah menyebar ke lebih dari 200 negara dan wilayah, dan pada 6 Mei 2020, Organisasi Kesehatan Dunia (WHO) telah melaporkan lebih dari 3.557.000 kasus COVID-19 yang dikonfirmasi, termasuk sekitar 245.000 kematian, baik di antara orang dewasa dan anak-anak. .("C2-Global-ResponsesWASH-COVID-19 (1),” n.d.)

Dokumen teknis ini menyajikan gambaran umum inisiatif yang diterapkan negara dan pemangku kepentingan dalam tanggapan COVID19 untuk memastikan layanan mencuci tangan untuk semua; khususnya dalam mengamankan dan mempertahankan akses ke layanan mencuci tangan untuk rumah tangga yang rentan serta di sekolah dan fasilitas perawatan kesehatan. Memastikan kebersihan yang baik dan praktik WASH yang sesuai untuk semua orang, di mana pun, akan membantu mencegah penularan virus COVID-19, tetapi juga akan mengurangi prevalensi penyakit menular lainnya dan mengurangi kerusakan tambahan, di luar kesehatan masyarakat.

METODE

Penelitian kuantitatif dengan pendekatan cross sectional. Rancangan penelitian adalah survey analitik dengan cara penyebaran kuisioner melalui online dengan media Whatshap. Pengambilan sampel penelitian dengan cara total sampling.Pengolahan data menggunakan analisis korelasi spearman rank.

\section{HASIL}

1.Distribusi karakteristik responden berdasarkan Jenis Kelamin

Tabel 1.1 Distribusi Karakteristik responden berdasarkan Jenis Kelamin

\begin{tabular}{lcc}
\hline Jenis Kelamin & $\mathrm{n}$ & $\%$ \\
\hline Perempuan & 24 & $60 \%$ \\
\hline Laki-laki & 16 & $40 \%$ \\
\hline Total & 40 & $100 \%$ \\
\hline
\end{tabular}

Distribusi karakteristik responden berdasarkan Jenis Kelamin dengan distribusi terbanyak perempuan yaitu $60 \%$ dan responden laki-laki $40 \%$.

2. Distribusi karakteristik responden berdasarkan usia

Tabel 1.2 Distribusi karakteristik reponden berdasarkan usia

\begin{tabular}{lcc}
\hline Umur (Tahun) & $\mathrm{n}$ & $\%$ \\
\hline Remaja akhir 17-25 & 38 & $95 \%$ \\
\hline Dewasa awal 26-35 & 0 & $0 \%$ \\
\hline Dewasa akhir 35-45 & 2 & $5 \%$ \\
\hline Total & 40 & $100 \%$ \\
\hline
\end{tabular}

Distribusi karakteristik responden berdasarkan Usia yaitu Remaja Akhir 17-25 Tahun dengan distribusi 95\% dan usia Dewasa akhir 5\%.

3. Distribusi karakteristik responden berdasarkan pengetahuan mencuci tangan

Tabel 1.3 Distribusi karakteristik responden berdasarkan pengetahuan mencuci

$\begin{array}{lll}\text { Pengetahuan Mencuci Tangan } & \mathrm{n} & \%\end{array}$

\begin{tabular}{lcc}
\hline Baik & 0 & 0 \\
\hline Cukup & 0 & 0 \\
\hline Tidak Baik & 40 & $100 \%$ \\
\hline Total & 40 & 100 \\
\hline
\end{tabular}

Distribusi karakteristik responden berdasarkan pengetahuan mencuci tangan yaitu dengan kategori Tidak baik sebanyak $100 \%$

4. Distribusi karakteristik responden berdasarkan motivasi mencuci tangan 
Tabel 1.4 Distribusi karakteristik kelompok usia ini paling rentan terhadap responden berdasarkan motifasi infeksi yang didapat dari tangan yang mencuci tangan tidak dicuci . Selain itu karena pada usia

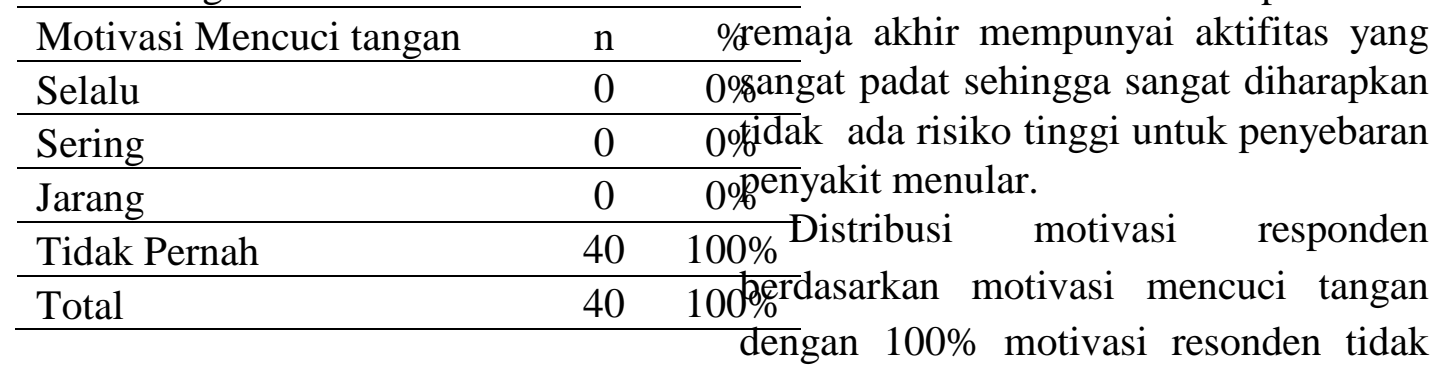

5. Analisis hubungan Pengetahuan dengan motifasi mencuci tangan

Hasil korelasi spearman rank yang di lakukan untuk mencari hubungan antara pengetahuan dan motivasi mencuci tangan di peroleh hasil 0,00.

Sedangkan hasil interprestasi menurut Sugiono (2008), berdasarkan besaran korelasi yang di gunakan, angka korelasi berkisar antara 0,00 0,199 dengan tingakat hubungan Sangat rendah.

\section{PEMBAHASAN}

Pada karakteristik responden terbanyak adalah perempuan dengan presentase $60 \%$. Perempuan merupakan responden terbanyak dalam menempuh pendidikan serta melalui pendidikan perempuan akan lebih cerdas dan bijak serta mempunyai wawasan lebih luas.

Pada Karakteristik responden distribusi responden berdasarkan berdasarkan usia yaitu $95 \%$ responden pada umur Remaja akhir. Tidak ada pembatasan umur dalam menempuh pendidikan namun pada usia remaja akhir merupakan usia terbaik dalam menempuh pendidikan sarjana.

Distribusi pengetahuan mencuci tangan dengan jumlah $100 \%$ tidak baik. Mencuci tangan yang benar adalah salah satu cara paling sederhana, paling terjangkau dan efektif untuk menghentikan penyebaran infeksi melalui tinja, cairan tubuh, dan benda mati. Mencuci tangan sangat penting bagi anak-anak dan remaja, karena pernah mencuci tangan. Mencuci tangan dengan air bersih dan sabun adalah salah satu tindakan paling dasar dan efektif untuk melawan COVID-19. Namun untuk melakukannya, diperlukan akses ke air bersih dan andal, fasilitas cuci tangan dengan sabun serta pengetahuan dan praktik mencuci tangan.

Analisis hubungan Pengetahuan dengan motivasi mencuci tangan di peroleh hasil 0,00 - 0,199 dengan tingkat hubungan Sangat rendah. Berarti tidak ada hubungan antara pengetahuan dan motivasi mencuci tangan . Kesadaran mencuci tangan sesuai standar WHO (World Health Organization) sangat berkaitan dengan pengetahuan dan memotivasi dalam mencuci tangan untuk mengurangi Wabah COVID-19 saat ini yang mengancam dan meningkatkan risiko tertular Covid-19.

\section{KESIMPULAN DAN SARAN \\ Kesimpulan}

Berdasarkan hasil analisa dan pembahasan maka di simpulkan: Pengetahuan mencuci tangan tidak baik, motivasi mencuci tangan tidak pernah dan sangat rendah dimana sangat terkait pengetahuan dan motivasi dalam mencuci tangan tidak ada hubungan. Dimana di harapkan peningkatan pengetahuan tentang mencuci tangan di 
sesuaikan dengan standar 6 langkah menurut WHO.

\section{Saran}

Saran atau rekomendasi untuk penelitian lebih lanjut dan memberikan pendidikan kesehatan tentang mencuci tangan dengan benar sesuai 6 langkah menurut WHO

\section{DAFTAR PUSTAKA}

Besha et al. (2016, DOI:10.4172/21611165.1000247). Assessment of Hand Washing Practice and it's Associated Factors Among First Cycle Primary School Children in Arba Minch Town,Ethiopia. Departemen of Nursing College of Medicine and Health Science, Arba Minch University, Ethiopia.

Ola, Keron Fransiska (2020). Virus Corona Mendekap Pertiwi, Kenali, Cegah dan Hindari. Pare-Pare, Sulawesi Selatan: Kaffah Learning Center

Note, I., Section, U., \& Technologies, I. (n.d.). Health \& nutrition during home learning, 1-6.

Sukesih, Usman, Setia B., Dian Nur A.S (2020). Pengetahuan dan sikap mahasiswa kesehatan tentang pencegahan Covid-19 di Indonesia. Jurnal Ilmu Keperawatan dan Kebidanan Vol.11 No.2 (2020) 258264

UNHCR. (2020). SUPPORTING

CONTINUED ACCESS TO EDUCATION DURING COVID19 Emerging Promising Practices. 